TRADITIONAL MEDICINE AND PHARMACOLOGY. ACHIEVEMENTS, INNOVATIONS, AND ALTERNATIVES

\title{
2.5 Механізми остеолізису та гіперкальциемії у хворих на В-клітинні хронічні лімфопроліферативні захворювання
}

У кістках здорової дорослої людині постійно відбувається відновлення КТ через координовану активність остеокластів (ОК) та остеобластів (ОБ) на поверхні трабекул та системі хейверсов. Існує урівноважена послідовність реконструювання: с початку, відбуваються процеси резорбції КТ, які $\epsilon$ результатом дії ОК, а потім формується кістка за рахунок функціювання ОБ.

Остеокласти походять 3 попередників остеокластів, що належать до моноцито-макрофагальної паростка. Але спочатку вони у неактивному стані. Певний вплив на активність остеокластів справляє макрофогальнийстимулюючий фактор мікрооточення КМ та ліганд рецептора RANKL (receptor activator of nuclear factor-kappa B), який розташовані на стромальних клітинах KT та на остеобластах. RANKL належить до сім’ї факторів некрозу пухлини (tumor necrosis factors). RANKL зв'язується 3 RANK рецептором, який розташований на попередниках остеокластів та за допомогою сигналу через ядерний фактор-B (nuclear factor-B(NF-B) та через Jun N-терминал киназний шлях (Jun N-terminal kinase) індукує синтез, активність остеокластів. Остеокласти виділяють (секретують) протеази та кислоту, які розчиняють матрицу кістки та сприяють резорбції органел клітин КТ. Рівень експресії RANKL залежить від остеотропних факторів таких як паратириоїдного гормону, 1,25-дігідроксівітаміна D3 та простагландинів. Активність RANKL рецептору також обумовлена рівнем розчинного рецептору остеопротегерину (OPGosteoprotegerin) [150-152]. OPG відноситься до сімейства рецепторів фактору некрозу пухлини (tumor necrosis factor receptors), який перешкоджає диференціюванню остеокластів та їх активності in vitro, in vivo. Остеопротегерин протидіє ефектам RANKL, він зв'язує RANKL і запобігає його закріпленню з рецептором RANK на остеобластах [151,153-155]. Сучасними експериментальними дослідженнями доведено, що у тварин, які мають малу кількість OPG розвивається остеопороз, а співвідношення між розчинними рецепторами OPG i RANKL регулює рівень та активність остеокластів 
TRADITIONAL MEDICINE AND PHARMACOLOGY. ACHIEVEMENTS, INNOVATIONS, AND ALTERNATIVES

[150,154,156-159]. Отже, система RANKL/OPG, відображає взаємодію цитокінів деструкції, антидеструкції кісткової тканини та гормонів, а порушення в співвідношенні RANKL/OPG призводить до деструктивних процесів у КТ.

Остеолізис є більш характерним для хворих на множинну мієлому (MM), що призводить до патологічних переломів, болю у кістках та гіперкальціемії. За результатами досліджень, на момент встановлення діагнозу до 80 \% хворих на ММ мають виражений біль у кістках, у 70 \% хворих патологічні переломи розвиваються впродовж хвороби [150]. Деструкція кісткової тканини (КТ) та гіперкальціємія корелює безпосередньо 3 масою мієломних клітин і має прогностичне значення [150,160,161].

У хворих на В-клітинні злоякісні лімфоми (ВЗЛ) з периферійних клітин при встановленні діагнозу тільки у 7\% діагностують вогнища лізису КТ без ураження інших систем та органів, а у 10-15\% хворих при прогресуванні хвороби. Завдяки вдосконаленню методів діагностики та впровадженню гістоморфометричних методів дослідження Rossi J.F. та співавт.,(1990) встановили, що у 80\% з первинно обстежених хворих на В-клітинні ЗЛ при відсутності кісткового болю та рентгенологічних данних, виявлено збільшення кількості як попередників остеокластів, так і зрілих остеокластів, які відповідають за резорбцію кісток [162]. За результатами Durr H.R. (2002), в середньому, тільки через 57 місяців після встановлення діагнозу ВЗЛ виявляються вогнища деструкції КТ при рентгенологічному дослідженні, а ще через 8-10 місяців хворі скаржаться на біль у кістках [163]. Доведено, що цитостатична терапія з використанням алкілуючих препаратів (ціклофосфамід), кортикостероїдів та променеве лікування хворих на ВЗЛ зменшує масу кісткової тканини та збільшує ризик виникнення остеолізизу у цих хворих [164]. Слід зазначити, що середній вік хворих на ВЗЛ дорівнює 45-50 років, а в цьому віці майже у $80 \%$ випадків виявляється остеопороз пов'язаний з гормональним дисбалансом, що в цілому сприяє посилюванню деструктивних процесів у КТ. 
TRADITIONAL MEDICINE AND PHARMACOLOGY. ACHIEVEMENTS, INNOVATIONS, AND ALTERNATIVES

\section{Фактори, що упливають процес остелізису при ВХЛПЗ.}

Остеолізис при ВХЛПЗ є перше за все результатом підвищеної активності остеокластів, а не дії самих пухлинних клітин. Однак, доведено, що кількість остеокластів збільшена на поверхні кістки тільки там де вони контактують 3 пухлиною, а їх активність пов'язана $з$ взаємодією із злоякісними клітинами та впливом остеокластактивуючих факторів (ОАФ), які виробляються як пухлинними клітинами, так і стромальними клітинами КМ $[150,161]$.

Вперше G.R. Mundy та співавт. (1996) в матеріалі культур клітин мієломної лінії ідентифікували білки, відомі як остеокластактивуючі фактори (ОАФ), що відповідають за деструкцію кісток у хворих на ММ. ОАФ включали в себе фактор некрозу пухлин (ФНП- $\beta$ ), інтерлейкін (ІЛ)-1 $\beta$ та інші [165].

Роль ІЛ- $1 \beta$ в деструкції КМ при ММ залишається дискутабельною. В дослідженнях G.R. Mundy та співавт. (1996) встановлено, що кількість ІЛ-1 $\beta$ в культурі клітин хворих на ММ була більшою, у порівнянні з групою контролю, а інгібітор цього цитокіну та його рецепторів був здатний запобігати процесам остеолізису [165]. Протилежні результати отримані S.J. Choi та співавт. (2000), які визначили у свіжій плазмі КМ хворих на ММ невисокий рівень IЛ-1 $\beta$, а АТ до цього білка не змінювали остеолітичну активність остеокластів [166].

Злоякісні плазматичні клітини хворих на MM також мають RANKL рецептор і можуть безпосередньо зв'язуватися з рецепторам RANK остеокластів та стимулювати їх активність [167]. Плазматичні клітини в процесі взаємодії 3 клітинами мікрооточення КМ при MМ збільшують рівень експресії RANKL рецептору на клітинах строми та зменшують кількість OPG [168-170]. Гіперекспресія рецептора RANKL є результатом діяльності мієломних клітин [167]. Експериментальні дослідження in vitro довели, що злоякісні плазматичні клітини здатні стимулювати RANKL експресію на стромальних клітинах та остеобластах частково через взаємодію клітини з клітиною, а частково через розчинні фактори [171]. Вважалося, що ОАФ, такі як ІЛ-1 $\beta$, ІЛ-6 і ФНП були результатом гіперпродукції стромальних клітин у відповідь на взаємодію 3 мієломними клітинами [172-174]. Однак, за іншими даними, RANKL-експресія 
TRADITIONAL MEDICINE AND PHARMACOLOGY. ACHIEVEMENTS, INNOVATIONS, AND ALTERNATIVES

не пов'язана з цими цитокінами. В дослідженнях N. Giuliani та співавт. (2001) встановлено, що блокування АТ ІЛ-1ß, ІЛ-6, і ФНП цитокинів не запобігало зниженню кількості експресії RANKL ліганду[168]. Протилежні результати, отримані K. C. Anderson та співавт. Raje N., [150,161], доводять, що ФНП безпосередньо здатний до активації остеобластів та сприяє збільшенню кількості експресії RANKL рецепторів на них. Ефекти ФНП реалізуються через стимуляцію активації транскрипційного фактору TRANCE (tumor necrosis factorrelated activation-induced cytokine), який стимулює транскрипцію специфічних генів, які залучені в процес деструкції кісткової тканини [169].

Рівень OPG фактору при ММ знижений як за рахунок зменшення його виробництва стромальними клітинами КМ, так і внаслідок конфіскації, засвоєння і деградації даного фактора мієломними клітинами $[168,169]$. Цей процес залежить від фізичної взаємодії між OPG та рецептором HSS-1 (heparane sulfates syndecan-1), який експресується на мієломних клітинах $[176,177]$.

Стромальні клітини, остеокласти та остеобласти КМ хворих на ММ є джерелом ІЛ-6 [156]. ІЛ-6 стимулює ріст пухлини, попереджуючи апоптоз пухлинних клітин при ММ та остеолізис КТ, та активуючи діяльність остеокластів, особливо, у присутності ІЛ-1 $\beta$ чи розчинного IЛ-6 рецептора (sIL6R) $[156,169,173,178,179]$. Отже, роль ОАФ, RANKL-стимулювання, ще остаточно невстановлені. Окремі роботи доводять вплив цитокінів ІЛ-7 та ІЛ-11 на рівень експресії RANKL рецепторів на остеобластах $[159,180]$.

Сучасними дослідженнями доведена роль ІЛ-3 в деструкції кісток при MМ [181, 182]. Виявлено, що кількість цитокіну ІЛ-3 збільшена в чисто ізольованій плазмі КМ хворих на ММ, у порівнянні з групою контролю. Низький рівень ІЛ-3 пов’язують із зменшенням остеолізу, в свою чергу, АТ, що блокують ліганд до ІЛ-3, зменшують діяльність остеокластів [182]. Експресується ІЛ-3 як злоякісними, так і ендотеліальними клітинами КМ хворих на ММ. Рівень експресії ІЛ-3 пухлинними клітинами корелює з агресивністю хвороби. ІЛ-3 зв'язується 3 трипептидом RGD в межах екстрацелюлярного матриксу, що призводить до безпосередньої активації остеокластів і резорбції кістки. Крім 
TRADITIONAL MEDICINE AND PHARMACOLOGY. ACHIEVEMENTS, INNOVATIONS, AND ALTERNATIVES

того, ІЛ-3 в комбінації з RANKL збільшують кількість та активність остеокластів [183]. Через ІЛ-3 мієломні клітини індукують експресію ІЛ-6. ІЛ-3 також приймає участь і в ангіогенезі при ММ [184]. Отже, цей цитокін впливає на всмоктування кісткової тканини, ангіогенез та швидкість розповсюдження пухлини.

Новітні дослідження показали роль гепатоцитарного фактору росту (HGF) в деструкції КТ при MM. HGF виробляється злоякісними плазматичними клітинами та [150,185] стимулює секрецію остеобластами IL-11 [186]. Високі рівні HGF в сироватці пов'язані з поганим прогнозом хворих на MM.

Роль макрофагального колонійстимулюючого фактору (М-КСФ) ще залишається до кінця нез'ясованою. В окремих роботах показано зростання рівня М-КСФ в сироватці хворих на ММ та встановлено прямий кореляційний зв'язок із об'ємом пухлини [187]. М-КСФ відіграє певну роль на ранніх стадіях розвитку остеокластів.

Дві незалежні групи дослідників встановили роль макрофагального інгібуючого протеїну $\alpha$ - та $\beta$ - (macrophage inhibitory protein-1, MIP-1 $\alpha$, MIP-1 $\beta$ ) в деструкції КМ при ММ $[187,188]$. В дослідженнях Ј.Н. Han та співавт. кількість MIP-1 протеїну у КМ хворих на ММ була більшою, в порівнянні з групою контролю [188]. М. Abe та співавт. встановили, що хемокіни MIP-1 $\alpha$ та MIP-1 $\beta$ секретуються мієломними клітинами і можуть безпосередньо зв'язуватися 3 рецепторами для MIP-1 $\alpha$ та MIP-1 $\beta$ (CCR5), які розташовані на поверхні попередників остеокластів та на стромальних клітинах КМ i, тим самим, стимулювати рівень експресії рецептору RANKL на стромальних клітинах KM, а,отже, і збільшувати остеолітичну діяльність остеокластів [187]. Відповідно до цих результатів, призначення нейтралізуючих AT anti-MIP-1 до 5TGM1 обмежувало розвиток деструкції КТ у мишей 3 мієломою [150]. Роль МIP-1 $\alpha$, MIP-1ß протеїнів в деструкції КТ при ММ підтверджена і клінічними дослідженнями $[188,189]$, які встановили прямий кореляційний зв'язок між тяжкістю деструкції кісткової тканини і експресією МIP-1 протеїну. Крім того, при вивченні профілю вираження генів встановилено, що ген MIP-1 $\alpha$ протеїну 
TRADITIONAL MEDICINE AND PHARMACOLOGY. ACHIEVEMENTS, INNOVATIONS, AND ALTERNATIVES

гіперекспресований при первинній MM [150]. Рецептор CCR5 також виражений на мієломних клітинах, в той час, як MIP- $1 \alpha$ і MIP-1 $\beta$ при ММ можуть діяти на пухлинні клітини аутокринним або паракринним шляхом [189]. В результаті подальшого вивчення встановлено, що MIP-1 викликає переміщення i сигналізацію каскадів механізмів зниження апоптозу, які сприяють виживанню і швидкому збільшенню мієломних клітин [190]. На додаток до їхньої остеокласт-індуктивної здатності, MIP-1 $\alpha$ і МІР-1 $\beta$ мають і іншу біологічну дію. Фактично, ці хемокини є могутніми модуляторами гемопоезу. MIP-1 $\alpha$ блокують ранній еритропоез, а МІР-1ß збільшує апоптоз пре-В клітин [191,192]. Тому, MIP-1 $\alpha$ та $-\beta$ є плюрипотентними хемокінами, що можуть відігравати важливу роль в патогенезі клінічних виявів ММ, включаючи не тільки деструкцію КТ, але i пригнічення еритропоезу, В-лімфопоезу та секрецію нормальних імуноглобулінів.

Окремі роботи продемонстрували, що самі мієломні клітини збільшують кількість остеокластів, діючи через остеобластні клітини. Експериментальні дослідження на мишах мієломної лінії підтверджують залежність активності остеокластів від дії на них мієломних клітин [150], але прямі взаємодії між мієломними клітками i остеокластами залишаються нез'ясованими. На плазматичних клітинах виявилено гиперекспресію гена, який кодує Gas-6 ліганд для рецептора тирозин кінази (tyrosine kinase Tyro-3), який задіяний в остеолітичному процесі [193]. Рецептор Туro-3 експресований на зрілих остеокластах, а гіперекспресія його ліганду на плазматичних клітинах може пояснити один 3 механізмів взаємодії між мієломними клітинами та остеокластами [194]. Проте, для підтвердження даної гіпотези, необхідно продовжити дослідження в цьому напрямку.

За даними літератури, вважалося, що остеолізис при ММ пов'язаний тільки з активністю остеокластів [195]. Сучасне гістоморфометричне вивчення та біохімічні індикатори обміну в КТ при ММ показали, що, хоча кількість остеокластів та їх функція збільшені при ММ, ключове розходження in vivo між присутністю та відсутністю літичних ушкоджень пов'язане, в першу чергу, зі 
TRADITIONAL MEDICINE AND PHARMACOLOGY. ACHIEVEMENTS, INNOVATIONS, AND ALTERNATIVES

зменшенням кількості та активності остеобластів у хворих на ММ з остеолізисом [195]. На ранніх стадіях ММ спостерігається збільшене формування КТ. Однак, при прогресуванні хвороби, цей процес сповільнюється, що веде до всмоктування і швидкої втрати КТ [156]. Припускають, що мієломні клітини можуть спочатку стимулювати функцію остеобластів на ранніх стадіях хвороби, а при збільшенні маси пухлини пригнічують їх. На сьогодні тільки окремі наукові роботи описують цю взаємодію між остеобластами та мієломними клітинами. Повідомлено про експресію мієломними клітинами інгібітора активності остеобластів DKK [196]. Фактично DKK1 блокує передачу сигналів, необхідних для диференціювання i функціонування остеобластів. Гіперекспресія DKK1 при MM пов'язана 3 лізисом КT. Однак, для підтвердження цих даних необхідні подальші експериментальні дослідження.

Іншим фактором взаємодії між остеобластами та пухлинними клітинами при MM є NCAM (neural cell adhesion molecule)/CD56. NCAM підтипу каппа гіперекспресується мієломними клітинами [197] та корелює з кількістю літичних вогнищ КТ [198]. Відсутність експресії антигену CD56 на мієломних клітинах або слабку його експресію асоціюють із низьким деструктивним потенціалом та тенденцією до циркуляції в периферичній крові злоякісних клітин [199]. Таким чином, зв'язування антигену CD56 пухлинних клітин при MM із NCAM остеобластів може зменшувати функцію остеобластів [151,200].

Завдяки новітнім дослідженням збільшується роль ангіогенезу як у патогенезі ММ, так і у процесі остеолізису $[150,156]$. Судинний ендотеліальний фактор росту (VEGF) продукується злоякісними плазматичними клітинами, $\mathrm{i}$ рецептор, що зв'язує цей фактор, виражений на клітинах строми КМ [200]. Фактично, сучасні результати показують, що VEGF збільшує секрецію IЛ-6 стромальними клітинами КМ хворих на ММ. Це може опосередковано привести до збільшеної втрати КТ в таких хворих. Донедавна не було даних, що VEGF приймає пряму участь в деструкції КТ. Однак, тепер доведено, що VEGF може заміняти M-CSF у розвитку остеокластів [201].

В результаті ряду досліджень встановлено, що у хворих на ВЗЛ 
TRADITIONAL MEDICINE AND PHARMACOLOGY. ACHIEVEMENTS, INNOVATIONS, AND ALTERNATIVES

деструктивні процеси у КТ також відбуваються за рахунок збільшення кількості та активності остеокластів. Roux S. та співав., (2000) довели, що у хворих на ЗЛ збільшується рівень експресії RANKL як на остеобластах, так і клітинах строми КМ, що і активує остеолітичну діяльність остеокластів [202]. В процесі взаємодії злоякісних лімфоцитів 3 клітинами мікрооточення збільшується рівень RANKL на остеобластах. Окрім того, автори встановили, що хемокіни MIP-1 $\alpha$ та MIP-1 $\beta$ секретуються пухлинними лімфоцитами і тим самим, стимулюють рівень експресії рецептору RANKL на стромальних клітинах KM, а, отже, і збільшують остеолітичну діяльність остеокластів [203]. Робота Atoyebi W. та співавт., (2002) показала, що під дією ОАФ таких як ІЛ-1, ІЛ-6 та ФНП зростає рівень експресії RANKL і тим самим збільшується активність остеокластів [204]. Отже з аналізу літератури можна зробити висновок, що фактори та механізми деструкції КТ як при ММ, так і при ВЗЛ $є$ аналогічними. Пояснення цього факту, в тому, що і ММ, і ВЗЛ належать до ХЛПЗ з периферичних клітин В-клітин.

Лабораторні маркери остеолізісу.

Для діагностики деструкції КТ, визначення ефективності лікування при ХЛПЗ та прогнозу хвороби визначають біохімічні індикатори обміну КТ, такі, як маркери остеолізісу та маркери формування КТ [205-208]. У хворих на ВХЛПЗ спостерігається збільшена кількість продуктів деструкції КТ (С-термінальний телопептид (колагену I типу) (C-terminal telopeptide of type I collagen), Nтелопептид пірідінолін (pyridinoline) і деоксипирідінолін (deoxypyridinoline) та зменшена кількість остеокальцину [209]. Окрім того, зменшення рівня остеокальцину та/чи збільшення концентрації ICTP (carboxy-terminal telopeptide of type 1 collagen ) передбачає скорочене виживання хворих [205]. В сучасному плацебо-контрольованому рандомізованому досліджені доведено, що більш високі рівні аміно-терміналу пропептиду (PINP), який є індикатором росту остеобластів та високі рівні лужної фосфатази (ЛФ) пов'язані 3 гіршим виживанням хворих на MM. Рівень PINP та ЛФ знижується при призначенні клодронату $[150,210]$. Зменшення вказаних маркерів упродовж терапії клодронатом було пов'язано 3 кращим виживанням хворих, при цьому 
TRADITIONAL MEDICINE AND PHARMACOLOGY. ACHIEVEMENTS, INNOVATIONS, AND ALTERNATIVES

спостерігалось, також, зниження маркерів остеолізису в сечі та зменшення кісткових ускладнень [150].

Інструментальні критерії деструкиї КT.

Найбільш інформативним та сучасним методом візуалізації вогнищ ураження КТ при ХЛПЗ вважається магнітно-резонансна томографія (МРТ) 3 контрастним посиленням Магневістом. У хворих на ХЛПЗ МРТ з контрастним посиленням у порівнянні з рентгенівською комп’ютерною томографією (КТ) вже на ранній стадії хвороби дозволяє провести диференційну діагностику між остеолізисом при ХЛПЗ та остеопорозом. Крім того, проведення МРТ у хворих на ХЛПЗ до та після лікування дозволяє судити об ефективності проведеної терапії.

Знеболююча, променева терапія та хірургічне лікування деструктивного процесу КТ при ХЛПЗ може ефективно зменшити наслідки цього процесу, але вказані методи не впливають на активність остеокластів, остеобластів та гуморальні механізми порушення обміну у кістках хворих на ХЛПЗ. Хіміотерапія зменшує масу пухлини та впливає тільки на окремі ланцюги остеолізису. Окрім того, остеолізис ускладнюється гіперкаціємією. За даними літератури гіперкаціємія встановлюється у 10\% хворих на В3Л та у 20-40\% хворих на ММ.

Препарати, щзо регулюють кістковий обмін.

Найбільш відомими інгібіторами кісткової резорбції є препарати класу бісфосфонатів (БФ). БФ - це нова група препаратів, що регулює кістковий обмін [210-212]. Вони є аналогами пірофосфату і містять дві фосфатні групи, які зв’язані атомом вуглеводу, формуючи структуру “Р-С-Р”[213]. Ця модифікація дозволяє запобігаючи ферментному гідролізу, забезпечує його біохімічну резистентність i, разом з тим, не перешкоджає у специфічному зв'язуванні та депонуванні БФ у кальцифікованій кістковій матриці. Гідроксильна група у структурі БФ, маючи високу схожість 3 кристалами гідроксиапатита мінерализованної частини кісткової матриці, сприяє запобіганню її розчинення, i, тим самим, зменшує як кількість остеокластів, так і їх активність з подальшим 
TRADITIONAL MEDICINE AND PHARMACOLOGY. ACHIEVEMENTS, INNOVATIONS, AND ALTERNATIVES

припиненням лізису кісток. Окрім того, БФ безпосередньо збільшують мінералізацію кісткової тканини, що сприяє зменшенню патологічних переломів $[198,200]$.

За даними останніх досліджень, за механізмом дії БФ можуть бути розподілені на дві групи. Метаболіти - такі, як клодронат і етідронат - можуть включатися в негідролізовані аналоги аденозину трифосфату (АТФ) шляхом метаболічних реакцій i, тим самим, інгібувати АТФ-залежні міжклітинні ферменти [213, 214]. До другої групи віднесено азот-утримуючі БФ (памідронат, аледронат, золедронат), які блокують ферменти не шляхом метаболізму, а внаслідок суттєвої зміни посттранслокаційної модифікації гуанідин трифосфатази (ГТФ) [213]. Таким чином, вони можуть запобігати біосинтезу складових білка ізопроноїда. Отже, блокування білка ізопроноїда та порушення функції ключових регулюючих білків пояснює один 3 механізмів зниження активності остеокластів та індукції апоптозу [158]. Окрім того доведено, що БФ блокують і мевалонову кислоту КТ, і, тим самим, змінюють рН КМ $[215,216]$. Під дією БФ зменшується кількість цитокіну ІЛ-6 в КМ хворих на ММ, що зменшує не тільки деструкцію КТ але виявляє і антимієломний ефект [217-219].

Сучасні результати експериментальних досліджень обгрунтували і антиангіогенезну дію БФ при ХЛПЗ, що дозволяє зменшувати не тільки літичні ушкодження КТ, але і швидкість прогресування хвороби [150].

V. Kunzmann i співавт. (1999) розкрили новий ефект дії БФ на Т-клітини. БФ стимулюють кількість $\gamma \delta$ Т-клітин у ПК та збільшують цитотоксичність Тклітин у культурі КМ, що може спричинювати як прямий, так i непрямий антипухлинний ефекти на мієломні клітини та злоякісні лімфоцити при ВЗЛ і тим самим зменшувати остеолізис [220]. Отримані дані підтверджені результатами експериментальних досліджень, які показали зменшення остеолітичного метастазування та збільшення виживання хворих після лікування БФ [221]. Описані результати лікування з ібандронатом на моделі мієломи у мишей, при якому спостерігали тільки зменшення остеолізису, проте, в цілому, терапія ібандронатом не впливала на перебіг захворювання та масу 
TRADITIONAL MEDICINE AND PHARMACOLOGY. ACHIEVEMENTS, INNOVATIONS, AND ALTERNATIVES

пухлини [222]. Результати пілотного дослідження M. Wilhelm та співавт., (2003) підтвердили, що комбінованому лікування препаратами IL-2 з БФ хворих на рефрактерні форми ВЗЛНСЗ, ММ дозволяє збільшити рівень $\gamma \delta \mathrm{T-клітин} \mathrm{у} \mathrm{ПК}$ хворих, що спричиняє антипухлинний ефект. Кількість об’єктивних відповідей у цих хворих дорівнювала $33 \%$.

Сьогодні ставиться питання вивчення ефективності та безпечності проведення лікування пацієнтів на ММ з урахуванням генетичних, молекулярно генетичних досліджень [223-226].

Таким чином, дані літератури та дані отримані нами свідчать, що хімічна активність клодронату є достатньою для досягнення клінічної ефективності. Лікування клодронатом сприяє зменшенню прогресування деструктивного процесу в кістках, істотно затримує час появи нових кісткових деструкцій, зменшує частоту патологічних переломів, сприяє регенерації КТ і консолідації патологічних переломів, забезпечує зменшення осалгічного синдрому, втрати кальцію і фосфору із сечею, поліпшує якість життя хворих. 